\title{
Ovarian Retiform Sertoli-Leydig Cell Tumor, Variant with Heterologous Elements
}

National Cancer Institute

\section{Source}

National Cancer Institute. Ovarian Retiform Sertoli-Leydig Cell Tumor, Variant with

Heterologous Elements. NCI Thesaurus. Code C126322.

A retiform Sertoli-Leydig cell tumor that arises from the ovary. It is characterized by the presence of an epithelial and/or mesenchymal heterologous component. 